$10-2015$

\title{
Why Moral Error Theorists Should Become Revisionary Moral Expressivists
}

Toby Svoboda

Fairfield University, tsvoboda@fairfield.edu

Follow this and additional works at: https://digitalcommons.fairfield.edu/philosophy-facultypubs Copyright 2015 Brill. A post print has been archived here with permission from the copyright holder.

\section{Peer Reviewed}

\section{Repository Citation}

Svoboda, Toby, "Why Moral Error Theorists Should Become Revisionary Moral Expressivists" (2015). Philosophy Faculty Publications. 22.

https://digitalcommons.fairfield.edu/philosophy-facultypubs/22

\section{Published Citation}

Svoboda, Toby. "Why Moral Error Theorists Should Become Revisionary Moral Expressivists", Journal of Moral Philosophy, Oct. 2015. 10.1163/17455243-46810047

This item has been accepted for inclusion in DigitalCommons@Fairfield by an authorized administrator of DigitalCommons@Fairfield. It is brought to you by DigitalCommons@Fairfield with permission from the rightsholder(s) and is protected by copyright and/or related rights. You are free to use this item in any way that is permitted by the copyright and related rights legislation that applies to your use. For other uses, you need to obtain permission from the rights-holder(s) directly, unless additional rights are indicated by a Creative Commons license in the record and/or on the work itself. For more information, please contact digitalcommons@fairfield.edu. 
Why Moral Error Theorists Should Become Revisionary Moral Expressivists

1: Introduction

Moral error theorists are in agreement that ordinary morality is deeply mistaken, holding that all moral utterances and judgments are expressions of false beliefs. However, there is substantial disagreement among error theorists concerning whether and how moral utterances and judgments should continue to be used. Suggestions in the literature include abolishing morality altogether [Garner 2007], adopting a fictionalist stance toward morality [Joyce 2001; Nolan et al. 2005], and the "conservationist" position of retaining morality unchanged [Olson 2011]. In this paper, I defend a fourth alternative, revisionary moral expressivism, the adoption of which would entail introducing non-cognitivist moral discourse and judgment to replace our current, cognitivist moral discourse and judgment. Briefly put, revisionary expressivists would recommend that we cease making moral utterances and judgments that express false beliefs and instead make moral utterances and judgments that express attitudes that are neither true nor false. I argue that revisionary expressivism should be taken seriously by moral error theorists, as it has significant advantages over the other three major positions that have been defended. In particular, revisionary expressivism avoids moral error while retaining several extremely useful features of morality, including the abilities to account for moral motivation, moral disagreement, and a kind of moral reasoning. Finally, since revisionary moral expressivism is a prescriptive metaethical thesis regarding what morality should become, it is not prone to many problems commonly associated with moral expressivism as a descriptive metaethical thesis. Since revisionary expressivists do not set out to describe how our current moral judgments and discourse operate, their recommendations (like those of prescriptive metaethicists in general) 
need not be constrained by certain facts about morality as it currently stands. This allows revisionary expressivists to avoid certain problems with relative ease.

Köhler and Ridge [2013] have defended a similar but distinct thesis. Unlike the present paper, however, Köhler and Ridge consider what should be done if all practical normative judgments turn out to be false. In that case, they argue that we should become "revolutionary expressivists" in all our practical normative judgments. Alternatively, my approach is concerned with what should be done if all moral judgments are false. As we will see, focusing exclusively on moral judgments allows us to avoid an objection that accepting a normative error theory undermines the normative claim that some practice should be adopted in light of error theory being true. In this paper, I first distinguish between descriptive and prescriptive metaethical theses and differentiate my own position from that of Köhler and Ridge. Second, I briefly sketch the theoretical commitments of moral abolitionism, revisionary moral fictionalism, and moral conservationism. Third, I discuss certain advantages and disadvantages for each of these three theories. Fourth, I examine what is entailed by revisionary expressivism. Fifth, I argue that revisionary expressivism has distinct advantages over the other three positions considered, concluding that it offers a very attractive position for those who accept moral error theory.

\section{2: Descriptive and Prescriptive Metaethical Theses}

To adopt a moral error theory is to accept a descriptive metaethical thesis, namely that (roughly) all actual moral utterances and judgments express false beliefs [Mackie 1977: 35, 4849]. This contrasts with classical expressivism, also a descriptive thesis, according to which all actual moral utterances and judgments express non-cognitive attitudes, such as desires or emotions [Ayer 1952: 44]. Whether either thesis is true depends on a matter of fact, namely the 
nature of actual moral utterances and judgments. I take no position in this paper regarding whether moral error theory is in fact true. Rather, I consider the implications for morality if moral error theory is true.

Each of the positions I examine makes a recommendation concerning what should be done with morality if moral error theory is descriptively true. Now one might immediately worry that this project is incoherent, since the descriptive truth of error theory might seem to undermine normative claims of any kind, including those regarding what should be done with morality. However, this concern would arise only on an error theory for normative judgments in general [see Bedke 2010; Streumer 2013]. If all normative judgments are false, then it would seem all claims about what we ought to do with morality are false. This is a challenge faced by Köhler and Ridge, which they call the "self-defeat problem." They recommend adopting "revolutionary expressivism" for all practical normative judgments if a normative error theory (and not just a moral error theory) is correct, but such a normative error theory arguably renders false their claim that we should adopt revolutionary expressivism [Köhler and Ridge 2013: 430-435]. Many error theorists, however, limit the scope of their theories to specifically moral judgments, such that some non-moral normative judgments are true, despite the fact that all moral judgments are false. If this distinction holds up, then the non-moral normative claims of prescriptive metaethics are not undermined by the truth of a descriptive moral error theory. My own claims in favor of revisionary expressivism are pragmatically normative (and perhaps, in the case of erroravoidance, epistemically normative) insofar as it counsels some course of action that should be taken because it would be useful to do so. Each of the prescriptive metaethical positions discussed in this paper purports to reduce the disadvantageous features of our present morality, preserve its useful features, or both. Thus, we can evaluate prescriptive metaethical theses in 
terms of the theoretical resources they possess or lack for delivering the useful features of morality while avoiding its disadvantageous features.

This strategy depends upon there being some problematic feature of moral judgments that is not shared by non-moral normative judgments. While this paper is not devoted to the question of whether moral error theory is descriptively true, something must be said to motivate this distinction between specifically moral and broadly normative error theories. In order for revisionary moral expressivism to get off the ground, there must be some plausible argument for moral error theory that does not likewise infect non-moral types of practical normative judgment. Lacking this, there will be trouble for the pragmatic normative claims that the revisionary moral expressivist wishes to make. If all practical normative judgments are false, then such claims would likewise be false. For this reason, it is arguably self-undermining for a revisionary expressivist to adopt an error theory for normative judgments and utterances.

Köhler and Ridge attempt to resist this self-defeat problem by arguing that their recommended variety of normative discourse preserves distinctive functions of our present normative discourse, such as by helping with both collective coordination problems and individual deliberation. Accordingly, the "should" in their recommendation is to be read as a functional "should" rather than a problematically normative one: if normative error theory is true, then we should adopt revolutionary expressivism because doing so allows normative discourse and judgment to perform their distinctive functions. But even if this maneuver avoids self-defeat, Köhler and Ridge recognize that their argument presupposes that we have good reason to favour the functions of normative judgment and discourse, and this appeal to good reasons would seem normative and thus suspect from the vantage of normative error theory. To deal with this problem, they note that normative judgment and discourse seem non-optional for 
human beings and that engaging in them tends to promote our interests. They then suggest a twostage strategy: first to identify what replacement of our current normative discourse would best preserve its distinctive (non-optional and beneficial) functions, and second to use this replacement discourse to argue that these functions are worth keeping. Köhler and Ridge admit that this strategy is circular, because it involves relying on revolutionary expressivism to argue for preserving these functions. Yet they deny that this move is viciously circular, because it does not beg the question against any rival prescriptive metaethical positions, all of which (with the exception of abolitionism) presuppose that these normative functions are worth preserving [see Köhler and Ridge 2013: 430-436].

Alternatively, my revisionary moral expressivism has a much easier time of avoiding these problems of self-defeat and circularity. First, since my position is restricted to moral normativity, the self-defeat problem is avoided from the start. There is nothing self-undermining about claiming that we (pragmatically) should adopt revisionary moral expressivism if a restricted moral error theory turns out to be true. Second, my approach is not circular, because I need not argue from the vantage point of revisionary moral expressivism that the functions of normative discourse and judgment are worth preserving. Instead, the revisionary moral expressivist can rely on pragmatic normative judgments of the sort we currently employ, using them to argue that moral discourse and judgment are in fact useful and thus worth keeping. There are advantages over the revolutionary expressivism of Köhler and Ridge. Accordingly, if it can be made to work, it seems more promising to adopt a revisionary expressivism restricted to morality than a revolutionary expressivism for all practical normative discourse and judgment. We can do this by restricting our error theory to our current morality. Normally moral error theorists find certain features of moral judgment to be objectionable that are not present in 
other types of practical normative judgment. Joyce, for example, takes issue with the categorical reasons that moral judgments are supposed to provide [Joyce 2001: 42]. On a view like this, what is suspicious about moral judgments is that they carry an unconditional to-be-doneness, such that one allegedly has reason (say) to perform some action even if there is nothing in one's motivational set that would speak in favor of doing so. Joyce contends that we cannot make sense of such reasons. They are "queer" in Mackie's sense. But other types of normative judgment arguably are different. Although they too involve to-be-doneness, this is plausibly taken to be non-categorical or conditional. When I judge that I ought (pragmatically) to perform some action, I am recognizing that I have reason to perform it, but this reason may be tied only to my contingent desires, goals, or projects. That I want $x$ and that $\varphi$-ing will get me $x$ provide me a pragmatic (but not moral) prima facie reason to $\varphi$. Under these conditions, $\varphi$-ing is useful because it is conducive to something that I want or to which I am already committed. Should the relevant desires, goals, or projects disappear, so will this pragmatic reason to $\varphi$, unless there are other items in my motivational set that are served by $\varphi$-ing. If we accept a view along these lines, pragmatic normativity will not be objectionable in the way of morality, for the former involves only reasons that are tied to the contingent motivations of agents. Unlike moral normativity, pragmatic normativity is reasonably taken to be conditional in this way. I hasten to add, however, that my case for revisionary moral expressivism does not depend on this particular account of pragmatic normativity being the correct one. All that is needed is some plausible way of distinguishing moral judgments from pragmatic ones, and this sketch indicates one reasonable way of doing so.

This also suggests a way of clarifying a pragmatic defense of revisionary moral expressivism. I will claim that we (pragmatically) ought to preserve morality because of its 
useful features, including interpersonal coordination and intrapersonal motivation. Such features can be useful in that they promote the desires, goals, or projects that many human beings in fact have. On this account, morality is useful at least as a contingent matter of fact, and so we have a conditional set of reasons to preserve it. This is admittedly a fairly thin account of our pragmatic reasons for preserving moral discourse and judgment, but the usefulness of morality seems fairly stable even if that is merely a contingent fact. On any plausible construal, many of our desires, goals, and projects seem well-served by intrapersonal motivation and interpersonal cooperation, perhaps due to stable facts about our psychology that are unlikely to change. Once again, my revisionary moral expressivism does not depend on this particular account of pragmatic usefulness, but it does illustrate a reasonable way of maintaining the needed distinction. Perhaps a more substantive account of pragmatic normativity could be made to work as well, such as by marking out items that are useful regardless of our desires, goals, or projects. One reason to be cautious of such a substantive approach, however, is that it risks straying into the (for the moral error theorist) problematic territory of appealing to categorical reasons. On a substantive account, it seems we should hold that you can have pragmatic reason to $\varphi$ even when $\varphi$-ing will get you nothing conducive to your desires, goals, or projects. This sounds like a reason of the sort that error theorists like Joyce find suspect. This is not to say that more substantive account must embrace categorical reasons, but the thin account of pragmatic normativity avoids this pitfall quite easily.

3: Moral Abolitionism, Revisionary Moral Fictionalism, and Moral Conservationism 
Before discussing my own revisionary expressivism, I examine three prescriptive metaethical positions that have been defended in the literature. According to these positions, if moral error theory is descriptively true, then...

(1): Moral Abolitionism: Morality should be abandoned altogether.

(2): Moral Conservationism: Morality should be maintained unchanged.

(3): Revisionary Moral Fictionalism: Morality should be maintained, but only in a fictionalist manner.

None of these positions purports to describe actual moral discourse or judgments. Rather, each position makes a recommendation for what should be done if all moral discourse and judgment are in fact mistaken. Moral abolitionists recommend that we do away with moral discourse and judgment entirely, given that they are comprised solely of falsehoods [Garner 2007; Hinckfuss 1987]. Moral conservationists recommend that we maintain our actual moral discourse and judgments as they are, despite the fact that they express uniformly false beliefs [Olson 2011, 2014]. Finally, revisionary moral fictionalists recommend that we continue to engage in moral discourse and judgment, but only in a fictionalist fashion [Joyce 2001; Nolan et al. 2005]. For purposes of clarification, it is necessary to consider revisionary fictionalism more closely, particularly the differing analyses of moral utterances that are offered by different versions of fictionalism.

There are two broad kinds of revisionary fictionalism one could adopt, namely content moral fictionalism and force moral fictionalism [Eklund 2011; Olson 2011: 185-186]. According to the former, moral utterances are assertions of some kind, such as ones made with an implicit 
fiction operator [Lewis 1978]. On a content moral fictionalist analysis, the utterance, "Murder is wrong," would be asserting that, within the fiction of morality, murder is wrong. On this view, moral utterances would be actual assertions, albeit assertions pertaining to a fiction. Alternatively, according to force moral fictionalism, moral utterances would not be genuine assertions. For example, moral utterances might be pretense assertions, such that someone making the moral utterance, "Murder is wrong," would only be pretending to assert that murder is wrong [Joyce 2001: 206-231].

Importantly, as a prescriptive metaethical thesis, revisionary moral fictionalism, whether in the guise of content or force fictionalism, does not hold that actual moral utterances or judgments are employed as fictions. Rather, revisionary fictionalists recommend that we adopt a fictionalist stance toward morality. This contrasts with hermeneutic fictionalism, which is a descriptive thesis holding that actual moral utterances are in fact employed in a fictionalist manner [Kalderon 2007; Eklund 2011]. I will consider neither hermeneutic fictionalism nor other descriptive metaethical theses further. Below, I discuss advantages and disadvantages of each of the three prescriptive positions already mentioned. Afterward, I present a fourth position: if moral error theory is true, then...

(4): Revisionary Moral Expressivism: Cognitivist moral discourse and judgment should be replaced with non-cognitivist moral discourse and judgment.

I argue that revisionary moral expressivism has significant theoretical advantages over positions (1)-(3), given that the theoretical commitments of revisionary expressivism secure useful features of morality while avoiding various difficulties that arise for these other views. The distinction 
between moral expressivism as a descriptive thesis and revisionary moral expressivism as a prescriptive thesis is important for seeing why it is coherent to accept the latter while rejecting the former. It may be that moral expressivism fails to describe morality as it stands now yet offers an attractive prospect for revising morality.

Before proceeding, let me say a few words about the argumentative strategy of this paper. Prescriptive metaethical theses should not be evaluated in the same way as descriptive metaethical theses. Obviously, since the former do not purport to describe actual matters of fact, they should not be judged according to how well they represent current moral discourse and judgment. Instead, I propose evaluating the four positions listed above by comparing their respective theoretical advantages and disadvantages. Advantages include possessing the conceptual means to avoid moral error while retaining useful features, such as the ability to allow and to account for moral motivation, moral disagreement, and moral reasoning. These features are useful at least in the sense that they are conducive to desires, goals, and projects many human beings have. Disadvantages include lacking the conceptual means to avoid moral error or to secure one or more of the useful features of morality. ${ }^{1}$ In the next section, I consider the theoretical commitments of abolitionism, revisionary fictionalism, and conservationism, as well as their respective theoretical advantages and disadvantages, in three different contexts: how these positions fare in avoiding moral error, how they fare in securing intrapersonal benefits of morality, and how they fare in securing interpersonal benefits of morality.

Among the three prescriptive positions I consider as competitors to revisionary expressivism, each has advantages but also major disadvantages. Moral abolitionism would

\footnotetext{
${ }^{1}$ It is important to note that I am not considering the practical challenges associated with actually transitioning from one kind of morality to another, focusing instead on whether different positions, once adopted, would secure the useful features of morality while avoiding various disadvantages.
} 
avoid moral error, but it also misses out on the useful features of morality. Revisionary

fictionalism might avoid moral error, but it has difficulty securing moral motivation and moral disagreement, and it might have difficulty salvaging moral reasoning. Finally, moral conservationism accounts well for moral disagreement, but it retains systematic moral error and accounts poorly for moral motivation.

\section{1: Avoiding Moral Error}

According to moral abolitionists, morality should be abandoned entirely [Garner 2007: 499]. Garner's abolitionism is motivated at least in part by his moral error theory. On his view, all moral utterances and judgments express uniformly false moral beliefs, and this provides good reason for abolishing morality. As Olson notes, abolitionism is a view that seems natural for error theorists to adopt, despite the fact that very few do so [2011: 180n83]. The view seems natural because, presumably, the fact that some utterance (or judgment) is false usually counts as a compelling reason not to make that utterance (or judgment). This seems perfectly sensible in many other error-theoretic cases, such as the case of phlogiston discourse [Nolan et al. 2005: 308]. However, many philosophers contend that morality is simply too useful to be abolished, even if moral discourse and judgment are deeply mistaken in the ways error theorists contend. Joyce argues that moral judgment can increase one's own self-control and help protect against weakness of will [2001: 215]. Nolan, Restall, and West argue that morality "plays an important social role in coordinating attitudes and in regulating interpersonal relations" [2005: 307]. Olson argues that literally false moral utterances are useful in interpersonal interaction because they conversationally imply imperatives (e.g., the utterance, "Murder is wrong" implies the imperative, "Do not murder"). Given this commitment to the usefulness of morality, others have 
sought to retain the "moral overlay" [Garner 2007: 501] of everyday moral discourse and judgment while also accepting the error-theoretic claim that all moral judgments and utterances are false.

The moral abolitionist might respond by granting that features such as interpersonal coordination are useful and thus worth preserving, but she might insist that these can be secured via non-moral means, such as various habits and preferences [Garner 2007: 512]. However, it is questionable whether non-moral habits and the like can provide interpersonal coordination just as well as morality, given that certain moral commitments seem especially well-suited to resolving disputes, such as when judgments about fairness are used to regulate allocations of scarce resources. If moral judgments about fairness are eliminated, it is unclear whether such disputes about allocation could be resolved by relying solely on the non-moral habits and preferences that we happen to possess. It seems that moral abolitionism comes with the cost (perhaps worth paying, perhaps not) of making interpersonal coordination more difficult.

Garner also holds that morality is actually more harmful than useful, primarily because it incurs heavy epistemic costs. He suggests that this would be the case even if moral discourse should be transformed according to fictionalist lights. In particular, he contends that revisionary moral fictionalism “undermines our epistemology by promoting a culture of deception" [2007: 499]. There is an epistemic tension involved in making utterances that one believes to be false, perhaps requiring "evasion, obfuscation, or sophistry just to maintain our fiction" [2007: 508].

In order to avoid objections of this kind, Joyce suggests that committed moral fictionalists should adopt a kind of non-cognitive stance toward their own moral utterances and judgments. Specifically, moral fictionalists could use their moral utterances to express "thoughts" rather than to express (false) beliefs. In this way, non-cognitivism "might become 
true if we were to alter our attitude towards moral discourse" [Joyce 2001: 201]. The idea here is that, since mere moral "thoughts" are not truth apt, they are not capable of being false. The advantage of this approach is that it potentially allows revisionary fictionalists to avoid making false moral utterances and holding false moral beliefs, perhaps sidestepping Garner's objection that moral fictionalism comes with unacceptable epistemic costs.

\section{2: Intrapersonal Costs}

However, Joyce's proposal faces problems of its own, since this non-cognitivist solution arguably undermines the advantages of revisionary moral fictionalism [Olson 2011: 195-196]. In particular, Joyce holds that moral discourse and judgment are worth maintaining because they have the intrapersonal benefit of increasing one's own self-control [2001: 184] by providing moral motivation, but it is unclear that this would be so if moral utterances and judgments merely expressed thoughts rather than beliefs [Köhler and Ridge 2013: 442]. For example, it is unclear why the mere thought that stealing is wrong would increase one's resolve not to steal. Admittedly, as Joyce stresses, "the decision to adopt morality as a fiction is not an ongoing calculation that one makes over and over" but rather "is something that occurred in the person's past, and now is an accustomed way of thinking..." [2001: 223-224]. This perhaps opens the way for Joyce to respond by claiming that moral thoughts bolster self-control due to a past decision to adopt a moral point of view throughout one's life. In that case, one's self-control would be enhanced not merely by a single moral thought, but by a moral thought together with this past decision to act in accordance with one's moral thoughts.

However, there seems to be a tension in Joyce's account between the efficacy of moral thoughts in strengthening self-control and the "self-surveillance" needed to root out one's (false) 
moral beliefs. According to Olson, "This leads to instability in that while ways of thought and behaviour likely to prompt moral belief are recommended, moral belief is to be avoided.

Occasional slips into moral belief are failures, even when they bolster self-control" [2011: 197]. Even if mere moral thoughts are capable of strengthening one's self-control, the concern is that motivationally efficacious moral thoughts easily slide into moral beliefs, whereas success in avoiding moral beliefs tends to reduce the motivational efficacy of moral thoughts. This tension makes it unclear whether Joyce's revisionary fictionalism has the advantage of maintaining morality's useful feature of strengthening one's own self-control, a consideration that is supposed to motivate a preference for revisionary fictionalism over abolitionism.

Olson's own moral conservationism fares somewhat better on this score but still faces problems. In particular, it is easier to see how moral beliefs (rather than moral thoughts) might be efficacious in strengthening one's self-control. If I believe that stealing is wrong, then it might seem plausible that my resolve not to steal will be stronger than if I lacked this belief. However, conservationism would still face objections from those who doubt that cognitivist theories of moral judgment adequately explain moral motivation. According to those who accept a Humean theory of motivation, for example, beliefs by themselves are incapable of motivating agents to act [Hume 2007 (1739): 266; Smith 1987]. If this is correct, then it remains unclear whether moral conservationism can deliver the increased self-control that moral discourse and judgment are supposed to provide. If the mere belief that stealing is wrong has no impact on my motivation to abstain from stealing, then it does not seem that this belief would serve to strengthen my selfcontrol in abstaining from stealing. Of course, there are critics of the Humean theory of motivation [Shafer-Landau 2003: 125], and perhaps Olson could offer a compelling case for why moral conservationism would in fact bolster self-control. One possibility is to respond that 
beliefs can play a motivational role even if they are not sufficient for motivation. For example, believing that some activity will bring pleasure might play a role in motivating one to pursue that activity, although some non-cognitive attitude (e.g., a desire for pleasure) might be necessary in order to be so motivated. Similarly, a conservationist might insist that moral beliefs support our moral motivation but are not sufficient for it.

Even granting the controversial view that beliefs can motivate, however, it is unclear that a belief can motivate someone who takes that belief to be false [Köhler and Ridge 2013: 439]. Imagine that someone who believes that stealing is wrong becomes convinced of moral error theory. According to moral conservationism, this person nonetheless should retain the false belief that stealing is wrong. Assuming it is possible to do this coherently (see below), it is very unclear that this belief would be motivationally efficacious. Indeed, it seems plausible that one's error-theoretic stance would undercut any motivational efficacy that the belief otherwise might have. This is because, if I accept moral error theory, I seem committed to a second-order belief that all my first-order moral beliefs are false. If that is the case, it is difficult to see how my firstorder moral beliefs, which I take to be false, could motivate me to practice greater self-control. Importantly, this is not a problem for moral error theory taken as a descriptive metaethical thesis, the truth of which I am assuming in this paper for the sake of argument. The main problem for conservationism here is that it is implausible to assume that beliefs taken to be false can motivate. This is not a difficulty faced by the descriptive error theorist, for she can argue that, although moral beliefs are false, they can motivate if taken to be true. Accordingly, this problem for conservationism does not undermine the assumed truth of moral error theory as a descriptive claim. 
Olson arguably avoids this problem, but only at great cost to his own position. His strategy is to attribute motivational efficacy not to moral beliefs themselves but rather to noncognitive attitudes of liking and disliking, which are correlated with moral beliefs. For example, someone who has the false belief that stealing is wrong probably also dislikes stealing. Hence, according to Olson, the moral belief that stealing is wrong might serve as a "reminder" of this dislike and thereby enhance one's self-control (via the non-cognitive attitude to abstain from stealing) to abstain from stealing [2011: 202]. This move is costly to Olson's position because it arguably makes the moral beliefs themselves superfluous in matters of moral motivation and self-control. If non-cognitive attitudes of liking and disliking do all the motivational work of enhancing our self-control, then why retain moral beliefs at all? Presumably, one could still benefit from the motivational efficacy of liking and disliking certain actions without having to remind oneself via (false) moral belief of what one actually likes or dislikes. Olson holds that, when we are tempted to steal, both our dislike of stealing and the belief that we normally dislike it "are typically not motivationally salient and perhaps even silenced," and in such cases he suggests that thinking to ourselves that stealing is wrong might reactivate their motivational salience [2011: 203]. It is not clear why Olson holds that one's dislike of stealing would lack motivational salience in such cases. Even if that claim is true, however, it seems implausible that reminding oneself of some false moral belief would reactivate the motivational salience of one's dislike of stealing. At the very least, it is unclear why this would be so.

Further, Olson's position seems to entail a very unwelcome epistemic tension, if not outright epistemic incoherence. This tension, which Olson recognizes [2011: 201], arises from accepting moral error theory while also retaining various moral beliefs. This involves holding two sets of beliefs: (1) some set of first-order moral beliefs and (2) a second-order belief that all 
first-order moral beliefs are false. This is an obvious tension, for it requires one both to affirm and deny various propositions, such as that lying is wrong. Leaving aside questions about the logic and epistemology of holding a belief that one takes to be false, the resulting tension from this odd conjunction of mental states is at least a disadvantage of Olson's position. All else being equal, some position that avoids this tension would be theoretically preferable.

\section{3: Interpersonal Costs}

In addition to bolstering self-control in intrapersonal cases, Olson follows Nolan, Restall, and West, who maintain that moral discourse serves the useful function of "coordinating and regulating individual and collective behaviour," including "inter- and intrapersonal reasoning and deliberation" [Nolan et al. 2005: 307]. Given that both revisionary fictionalists and conservationists purport to preserve these useful features of morality, their positions aim to account for both moral disagreement and the possibility of moral reasoning. Olson claims that revisionary fictionalists can achieve only one or the other of these goals, depending on whether they adopt content or force moral fictionalism [Olson 2011: 186]. Specifically, he contends that force moral fictionalism faces the Frege-Geach problem, whereas content moral fictionalism cannot account for moral disagreement.

The Frege-Geach problem [Geach 1958; Schroeder 2008] typically arises for moral noncognitivists when it comes to accounting for cases of apparent moral reasoning. Consider Peter Geach's example: "If doing a thing is bad, getting your little brother to do it is bad. Tormenting the cat is bad. Ergo, getting your little brother to torment the cat is bad" [Geach 1965: 463]. This seems to be a valid modus ponens argument comprised of moral propositions. Someone who utters these three sentences seems to be making a kind of inference whereby the third sentence 
follows from the conjunction of the first two sentences. Otherwise put, the truth of the first two sentences would seem to guarantee the truth of the third. It is a challenge for non-cognitivists to explain how moral utterances, which on their account do not express beliefs in propositions, can figure into such cases of apparent moral reasoning [Blackburn 1984: 189-196; Gibbard 2008]. According to Olson, force moral fictionalists face a similar difficulty, because on their account participants in moral discourse merely pretend to assert (and merely pretend to believe) moral propositions, and such pretense assertions (and beliefs) cannot figure into cases of genuine moral reasoning and inference [Olson 2011: 189-192]. He suggests that someone who merely pretends to assert propositions that are incompatible with each other may not be charged with inconsistency, given that she does not genuinely assert or believe in an inconsistent fashion [2011: 191]. While force moral fictionalists might be able to develop a satisfactory account of moral reasoning and inference, I take it that Olson has shown that they cannot avoid the FregeGeach problem in a straightforward fashion [cf. Nolan et al. 2005: 317]. This is a disadvantage for revisionary force moral fictionalism in comparison to moral conservationism, since the latter is able to account for moral reasoning in terms of valid inferences among (false) propositions that are genuinely asserted and believed.

Alternatively, content moral fictionalism faces difficulties in accounting for moral disagreement [cf. Nolan et al. 2005: 319-320], at least among moral fictionalists themselves. Olson imagines a consequentialist and a deontologist who offer different verdicts regarding what ought to be done in some particular case [2011: 186]. Typically, we would say that this is a case of moral disagreement. Arguably, however, the consequentialist and the deontologist are working within different moral fictions. If that is the case, then it is unclear that they disagree with each other. In some particular case, the consequentialist's moral utterance might amount to, 
"Within the moral fiction of consequentialism, $\varphi$-ing is permissible," whereas the deontologist's moral utterance might amount to, "Within the moral fiction of deontology, $\varphi$-ing is impermissible." This would not entail disagreement between the consequentialist and the deontologist [2011: 186-187], since both could agree that $\varphi$-ing is permissible according to the fiction of consequentialism but that $\varphi$-ing is impermissible according to the fiction of deontology. Thus, it is not evident how content moral fictionalists can account for moral disagreement. This is a drawback for revisionary content moral fictionalism, as it is arguably a useful feature of moral discourse to track normative and evaluative disagreements among human beings.

Finally, I would add that force moral fictionalism also has difficulty accounting for moral disagreement among persons. Genuine interpersonal disagreement seems to require that two or more persons be at odds with one another over some issue. Two individuals who merely pretend to believe or assert incompatible propositions do not seem genuinely to disagree with each other. Although their moral pretenses are at odds, neither person harbors some genuine commitment that could be at odds with some genuine commitment of the other. Thus, it is unclear whether revisionary force moral fictionalism can underwrite genuine interpersonal disagreement on moral matters. Now perhaps force moral fictionalists could appeal to something like disagreement in attitude [Stevenson 1979], holding that there can be disagreement among persons who take conflicting attitudes toward some fiction, as when two individuals respectively like and dislike the same fiction. But this move would involve appealing to arguably non-moral attitudes that are only contingently connected to our moral judgments. After all, on revisionary force moral fictionalism, moral judgments would be pretense beliefs rather than non-cognitive attitudes, so attitudes regarding our moral fiction must be something additional. As we shall see, revisionary 
moral expressivism can appeal to disagreement in attitude in a straightforward fashion, for if adopted then our moral judgments themselves would be non-cognitive attitudes, and judgments of this kind allow for disagreement in an attitudinal sense by their very nature.

To summarize, abolitionism has the advantage of avoiding moral error but the disadvantage of sacrificing the useful features of morality; revisionary fictionalism avoids moral error but has difficulty delivering moral motivation, moral disagreement, and (in the case of force fictionalism) moral reasoning; conservationism accounts for moral reasoning and disagreement but involves systematic moral error and gives an unsatisfactory account of moral motivation.

\section{4: Developing Revisionary Moral Expressivism}

With the exception of Köhler and Ridge [2013]—whose "revolutionary expressivism" for all normative judgments and utterances entails revisionary expressivism for morality but is not limited to the moral domain — revisionary moral expressivism has been neither developed nor defended in the literature, despite similar ideas being recognized as possible positions [Blackburn 1993; Olson 2011: 202]. As we have seen, Köhler's and Ridge's normative expressivism faces some problems that a specifically moral expressivism can straightforwardly avoid. I argue that if moral error theory is true, then we should adopt revisionary expressivism, given that it has major advantages over its competitors. First, however, I shall sketch what the position entails.

By "revisionary expressivism" I mean a prescriptive metaethical thesis that recommends adopting expressivist, non-cognitive moral discourse and judgment and jettisoning any cognitivist moral discourse and judgment. Revisionary expressivists hold that we should 
(understood in a pragmatic sense) cease making moral utterances and judgments that express beliefs, replacing them with ones that express non-cognitive attitudes. For a moral error theorist, the rationale behind this transition is that it would free us from the systematic errors that comprise current morality. Different versions of revisionary expressivism are available, insofar as there are different versions of expressivism, such as emotivism and prescriptivism. Because of this, revisionary expressivism can be understood as a family of related views. The central commitment shared by these views is that moral judgments should be transformed into desirelike attitudes, and moral utterances into expressions of such attitudes. This distinguishes revisionary expressivist views from revisionary views holding that moral judgments should be beliefs (cognitivist views, including moral conservationism ), that moral utterances should be assertions (revisionary moral fictionalism of the content variety), or that moral judgments and utterances should be pretenses (revisionary moral fictionalism of the force variety). I will not defend any particular version of revisionary expressivism here, instead noting the theoretical virtues possessed by revisionary expressivism in general.

One way of transitioning to revisionary expressivism is for participants in moral discourse to bring their moral language into line with some kind of expressivism. Many of our actual moral utterances have cognitivist trappings, such as assertoric surface grammar [ShaferLandau 2003: 23-24] and truth attribution. Consider the moral utterance, "It is true that donating to charity is morally obligatory." The sincere utterance of this sentence seems to express a moral belief, namely that donating to charity is morally obligatory. According to revisionary expressivism, the speaker in question should abandon both his moral beliefs and the false moral utterances that express them. One could do the latter by extirpating both (1) the assertoric features of his moral discourse and (2) any attribution of moral truth within his moral discourse. 
The replacement moral discourse would be recognizably non-cognitivist. Instead of saying, "It is true that donating to charity is morally obligatory," one might say, "Hooray for donating to charity!" or "Donate to charity," and these utterances would remain moral insofar as they would be expressions of moral judgments.

Now perhaps revisions to our entire moral discourse are unnecessary in order to avoid moral error. For example, although the moral utterance, "One ought to donate to charity," has the surface grammar of an assertion, revisionary expressivists plausibly could use it to express a non-cognitive attitude, such as approval of donating to charity, rather than a belief, such as that one ought to donate to charity. Likewise, the moral utterance, "Indifference to suffering is bad," might be expressive of the speaker's disapproval of indifference to suffering rather than of some (false) moral belief. Hence, revisionary expressivists need not make the perhaps extreme proposal that all participants in moral discourse should transform each of their moral utterances into a transparently emotivist, prescriptivist, or otherwise non-cognitivist expression. As moral quasi-realists note, realist-sounding discourse is compatible with expressivism [Blackburn 1993: 184-186].

However, it seems reasonable for revisionary expressivists at least to reduce the occurrence of cognitivist-seeming features in their moral discourse. Whereas the project of quasi-realism involves accounting for our actual moral discourse (including its cognitivist trappings) in expressivist terms, the project of revisionary expressivism involves developing a variety of moral discourse and judgment that retains the useful features of our present morality while avoiding its errors. Thus, unlike quasi-realism, revisionary expressivists may recommend the elimination of those features of moral discourse that are mistaken or misleading. Importantly, this means that some objections to expressivism as a descriptive thesis do not apply to the 
prescriptive thesis of revisionary expressivism. One might contend that the former fails to account satisfactorily for both the surface grammar of our actual moral utterances and the phenomenology of our actual moral judgments, both of which seem to be better described by cognitivist accounts. The revisionary expressivist can accept this, because she takes our actual moral judgments and utterances to be cognitivist in nature, although she recommends that we alter them so that they become non-cognitivist in nature. While it might not be necessary to dispose of all instances of assertoric surface grammar, it seems appropriate at least to jettison predication of truth or falsity within our moral utterances. If moral error theory is true, then employing truth predication in our moral utterances is arguably a misleading way of speaking. Admittedly, this may not be the case if some minimalist theory of truth holds for such utterances, for "It is true that murder is wrong" would then express nothing more than "Murder is wrong" [Smith 1994]. But revisionary expressivists who are not committed minimalists seem welladvised to dispose of truth predication in their moral utterances, since this minimalist move is not open to them. Moreover, even revisionary expressivists who are committed minimalists may have reason to jettison truth predication in moral discourse, given that they will have to interact with others (including non-philosophers!) who are not so committed. Others might easily misinterpret "truth talk" on the part of minimalists and be misled by it, and this in turn might threaten interpersonal coordination.

A second way to transition to revisionary expressivism is for participants in moral discourse to alter their moral judgments, abandoning moral beliefs and replacing them with noncognitive attitudes. Indeed, this transition is crucial for revisionary expressivism, given that the motivation behind it is to eradicate epistemic error while preserving the useful features of morality. We can characterize beliefs and non-cognitive attitudes according to their directions of 
fit [Ridge 2007: 96-97; Smith 1994: 115; cf. Sobel and Copp 2001]. While beliefs have a "mindto-world" direction of fit, non-cognitive attitudes have a "world-to-mind" direction of fit. That is, beliefs are mental states that attempt to fit with the world, such as by representing it accurately, whereas non-cognitive attitudes are mental states, such as desires, that attempt to make the world fit with them. According to the error theorist, moral beliefs are false because they fail to fit with the world, given that there are no moral facts in the world for those beliefs to fit with [Mackie 1977: 48-49]. Moral judgments that express non-cognitive attitudes, conversely, are not subject to such error. This is because they do not purport to fit the world but rather to mold the world according to the non-cognitive attitudes being expressed (e.g., desires, emotions, or imperatives). By abandoning moral beliefs, the revisionary expressivist can avoid systematic error. By instead making judgments that have exclusively a world-to-mind direction of fit, however, revisionary expressivism preserves the useful features of moral discourse and judgment—or so I argue below.

Finally, it is important to note that revisionary expressivism differs significantly from the position recommended by Joyce that was discussed above. While Joyce urges adopting a noncognitivist stance towards one's moral utterances [2001: 201], his position remains a species of revisionary fictionalism. In particular, Joyce recommends a kind of force moral fictionalism, whereby one's moral utterances are treated as pretense assertions that express thoughts rather than beliefs. This position is non-cognitivist in the sense that moral utterances are not straightforwardly truth apt, but otherwise it bears little resemblance to the various kinds of expressivism that have been defended [Ayer 1952; Blackburn 2001; Gibbard 1992; Stevenson 1979]. Unlike revisionary fictionalism, revisionary expressivism does not counsel that participants in moral discourse make either genuine or pretense moral assertions. Instead, 
revisionary expressivists would use their moral utterances non-assertively to express their noncognitive moral judgments, whether these be emotions, desires, attitudes of some other kind, or imperatives. $^{2}$

Now one might object that revisionary expressivism does not deliver genuinely moral judgments and utterances. After all, if moral error theory is descriptively true, then our actual moral judgments and utterances involve beliefs and expressions thereof, respectively. Since revisionary expressivism recommends that we replace these with non-cognitive attitudes and expressions thereof, what reason is there to consider the resulting kind of judgment and discourse to be moral? Revisionary expressivism might even be deemed a species of moral abolitionism, given that, if error theory is descriptively true, it would abolish morality as we know it, replacing it with something new.

Whether this objection goes through depends on what makes some kind of judgment or discourse moral. If moral judgments necessarily involve beliefs, for example, then revisionary expressivist judgments are not genuinely moral ones. However, there is good reason to suspect that the best conceptions of what moral judgment and discourse can be are general enough to permit non-cognitivist varieties. After all, while traditional cognitivists reject the view that moral judgments and utterances are in fact non-cognitivist, this is grounded in their finding noncognitivism problematic in some respect (e.g., due to the Frege-Geach problem or failing to account for the surface grammar of actual moral utterances [Shafer-Landau 2003: 23-24]) other than its alleged failure to deliver genuinely moral judgments and utterances. Further, in order to avoid begging the question against non-cognitivists (e.g., by defining a moral judgment in

\footnotetext{
${ }^{2}$ One might object that this way of avoiding moral error comes at the high cost of weakening our moral judgments (e.g., that genocide is deeply wrong), reducing them to mere contingent preferences (e.g., a dislike for genocide). However, non-cognitive attitudes need not be weakrather, they can be deep-seated and widely shared, even if they are contingent.
} 
cognitivist terms), cognitivists initially must work with some conception of moral judgment or discourse that is general enough to be susceptible to both cognitivist and non-cognitivist accounts. These considerations suggest that moral non-cognitivism would yield judgments and utterances that are recognizably moral. Importantly, this is consistent with supposing that moral error theory is descriptively true, for that truth may simply reflect contingent features of our current morality rather than necessary ones. Now perhaps moral non-cognitivism is merely an epistemic possibility, such that, if we knew better, we would realize that expressivism is not a properly moral position. But in the absence of compelling reasons to think this, it is reasonable to take revisionary expressivist judgments and utterances to be genuinely moral, given that noncognitivism is generally viewed as a viable (although perhaps false) account of moral discourse and judgment.

\section{5: The Case for Revisionary Moral Expressivism}

We are now in a position to compare the merits and deficiencies of revisionary moral expressivism to those of the other three prescriptive metaethical theses discussed in the third section of this paper. I argue that, if moral error theory is true, then revisionary moral expressivism has substantial theoretical advantages over abolitionism, revisionary fictionalism, and conservationism.

\section{1: Avoiding Moral Error}

The most obvious benefit of revisionary expressivism is that it avoids systematic moral error, given that expressivist utterances and judgments are not capable of being false, except perhaps in a minimalist sense [see Dreier 2004; Smith 1994]. Assuming with the error theorist 
that there is no moral truth to be had, it is epistemically preferable to adopt a kind of moral discourse and a kind of moral judgment that do not purport to represent moral facts. On this score, revisionary expressivism fares much better than moral conservationism, which explicitly recommends holding false beliefs and making false utterances. Revisionary expressivism also has an epistemic advantage over those versions of moral fictionalism that require moral speakers to engage in a deceptive discourse [see Garner 2007: 499], since revisionary expressivism does not rely on moral speakers making false utterances.

Adopting revisionary expressivism is not the only way to avoid such epistemic and linguistic error, of course. Moral abolitionism averts moral error by simply doing away with morality altogether, whereas Joyce's moral fictionalism arguably does so by using moral utterances to express thoughts rather than beliefs. As we saw above, however, both these positions avoid moral error at the cost of missing out on some or all of the useful features of morality. Revisionary expressivists, conversely, can both avoid moral error and retain many of these useful features, as we shall shortly see.

\section{2: Preserving the Intrapersonal Benefits of Morality}

Intrapersonal motivation is a feature of morality worth preserving because it bolsters one's commitment to act for certain ends, increases one's self-control, and helps overcome weakness of will. Revisionary moral expressivists can account for intrapersonal motivation in terms of the Humean theory of motivation. Like expressivists in general, revisionary expressivists can understand moral judgments as desire-like attitudes that have inherent motivational force. For example, if the moral judgment that lying is wrong is understood as a desire-like attitude with respect to lying (e.g., disapproval of it), it is easy to see why the person 
making this judgment would be motivated to some degree not to lie. The revisionary expressivist thus can help herself to a straightforward account of intrapersonal motivation, thus preserving a very useful feature of morality while avoiding any epistemic error in the process.

Conversely, by doing away with morality entirely, moral abolitionists relinquish the intrapersonal motivation moral judgments can provide. All else being equal, this makes revisionary expressivism more attractive than abolitionism. Revisionary moral expressivism also has a significant advantage over revisionary moral fictionalism on this point. As discussed above, it is difficult to see how either force or content fictionalism could secure intrapersonal motivation, given that the belief that morality is a fiction would seem to undermine morality's motivational efficacy. If this is correct, then moral fictionalism relinquishes a very useful feature of morality as well. Again, revisionary expressivism is theoretically preferable here, because it need not explain how beliefs taken to be false can motivate. Instead, revisionary expressivists can explain intrapersonal motivation quite straightforwardly in terms of desire-like attitudes.

Let us now consider conservationism. As noted above, it is unclear that moral beliefs taken to be false could provide any motivation, even assuming that the Humean theory of motivation is false. Olson deals with this problem by appealing to non-cognitive attitudes that are correlated with our false moral beliefs, with these non-cognitive attitudes doing the motivational work, or at least much of it [Olson 2011: 202]. However, this move cedes an important point to revisionary expressivists, namely that desire-like attitudes are needed to account for moral motivation. Moreover, on Olson's account, moral motivation is only contingently connected to one's moral judgments, since it arises from attitudes of liking or disliking that happen to be associated with such judgments. Thus, intrapersonal motivation sometimes (perhaps often) might not accompany moral judgments. This result is unfortunate for a prescriptive metaethical 
position. Such a position is supposed to preserve intrapersonal motivation as a useful feature of morality, but Olson's conservationism establishes only a contingent link between moral judgment and motivation. Revisionary expressivism, conversely, matches internalist intuitions by establishing a necessary link between the two [Smith 1994: 72]. By recommending that we only make moral judgments that are desire-like attitudes, revisionary expressivists can straightforwardly secure intrapersonal motivation as an essential component of moral judgment, given that desire-like attitudes are inherently motivational.

\section{3: Preserving the Interpersonal Benefits of Morality}

Revisionary moral expressivism also delivers certain interpersonal benefits, such as tracking normative disagreement and allowing for a kind of moral reasoning among various parties. As we saw above, both force and content moral fictionalism face difficulties in accounting for moral disagreement. All else being equal, a position that accommodates moral disagreement would be preferable to either of these kinds of moral fictionalism.

Revisionary moral expressivists can understand moral disagreements as disagreements in attitude rather than disagreements in belief [Stevenson 1979: 4]. An obvious case of such disagreement is that of two persons who respectively approve and disapprove of the performance of the same action. If a poor person steals a valuable item from a wealthy neighbor, two observers might harbor divergent attitudes with respect to that instance of stealing: one might approve of it while the other disapproves of it. The revisionary expressivist, like expressivists in general, can explain this disagreement in terms of attitudinal differences, such as that (say) the former observer desires a redistribution of wealth by whatever means necessary, whereas the latter desires that the status quo remain unchanged. It is important to note that the revisionary 
expressivist need not explain any disagreement in moral belief since, if her advice was taken, there would be no moral beliefs at all, only non-cognitive moral attitudes. Despite this, revisionary expressivism preserves the useful feature of accounting for normative and evaluative disagreement, because it can track these as attitudinal divergences.

Arguably, revisionary expressivism also can accommodate a kind of moral reasoning as well, thus facilitating interpersonal coordination even among those with initially divergent moral attitudes. The chief obstacle to this is posed by the Frege-Geach problem. As mentioned above, it is a challenge for non-cognitivists, including revisionary expressivists, to explain how moral judgments can figure into apparently valid arguments. Descriptive expressivists have offered responses to this challenge, such as Blackburn's logic of attitudes, which permits inferences among non-cognitive moral judgments [Blackburn 1984: 189-196]. Consider again Geach's example of moral reasoning: "If doing a thing is bad, getting your little brother to do it is bad. Tormenting the cat is bad. Ergo, getting your little brother to torment the cat is bad" [1965: 463]. On Blackburn's approach, very briefly put, the first sentence in this argument expresses disapproval of making one's brother perform an action of which one disapproves; the second sentence expresses disapproval of tormenting the cat; and the third sentence expresses disapproval of making one's brother torment the cat. Although none of these sentences expresses a truth-apt belief, the third sentence follows from the previous two in the sense that it would be inconsistent —or at least would betray a "fractured sensibility" — to hold the attitudes expressed by the first two sentences but fail to hold the attitude expressed by the third sentence [Blackburn 1984: 195-196].

One objection to Blackburn's approach is that it does not secure logical inferences among moral judgments but only establishes that holding some moral judgments requires holding 
certain others in order for one to be pragmatically consistent in one's attitudes [Hale 2002]. If this objection is correct, then Blackburn's account does not explain how the first two sentences in Geach's example logically entail the third, although it does explain why it would be inconsistent for practical purposes to hold the first two judgments while not holding the third. Even if this objection goes through, however, Blackburn's account might be sufficient to ground a kind of moral reasoning among revisionary expressivists. If we grant that expressivist moral judgments do not admit of logical relations among one another, they still provide good pragmatic reasons to those who hold them (e.g., to adopt or relinquish some moral attitude), and this may be enough to establish the possibility of moral reasoning and the interpersonal coordination such reasoning can afford. Consider someone who holds the non-cognitive attitude of disapproving of capital punishment. In a moment of unrestrained fervor, this person might express satisfaction at the execution of some particularly heinous criminal. A friend of this individual might point out that this satisfaction is (pragmatically) inconsistent with the attitude of disapproving of capital punishment, and this might open the way for a rational conversation between the two persons regarding how one's various moral attitudes should be modified in order to be consistent. Since non-cognitive attitudes are susceptible to such pragmatic evaluation, they can figure into cases of such moral reasoning. ${ }^{3}$ Now if expressivism has the resources to handle the Frege-Geach problem, one might ask why we should not be descriptive expressivists in the first place. One answer is that our actual moral discourse has the surface grammar of a cognitivist discourse, which suggests that expressivist analyses do not accurately reflect our actual moral discourse.

\footnotetext{
${ }^{3}$ Admittedly, the cognitivist resources of conservationism might allow for a more straightforward account of moral reasoning, insofar as it can recognize valid inferences among false moral beliefs. Nonetheless, revisionary expressivism seems able to preserve the useful feature of allowing for a kind of moral reasoning, even if that is based on pragmatic consistency rather than logical validity.
} 
A similar response to the Frege-Geach problem also might be available to force moral fictionalists, since they could argue that we should maintain pragmatically consistent pretenses. If so, then force moral fictionalism and revisionary expressivism would be on equal footing with respect to the Frege-Geach problem. Yet there are other reasons to prefer revisionary expressivism to force moral fictionalism. First, we have already observed that revisionary expressivism fares better in preserving moral motivation, since it is unclear that pretense beliefs (or to follow Joyce, moral "thoughts") can secure moral motivation while maintaining vigilance in avoiding moral error. Second, revisionary expressivism fares better in accounting for moral disagreement. As we have seen, since force moral fictionalists only pretend to assert and believe moral propositions, it is unclear that there can be genuine interpersonal disagreement among them regarding moral issues [Olson 2011: 190-191]. While the propositions two force moral fictionalists pretend to believe can be inconsistent with each another, they do not harbor genuine commitments (e.g., beliefs or desire-like attitudes)that would admit of such inconsistency, and this would seem to allow for only pretense moral disagreement among force moral fictionalists. Conversely, there could be genuine moral disagreement among revisionary expressivists, because they genuinely hold attitudes that are capable of being pragmatically inconsistent with one another.

Revisionary moral expressivism has significant advantages over the other metaethical theses considered in this paper. It avoids moral error while preserving and accounting well for moral motivation, moral disagreement, and moral reasoning. We thus have excellent reason to prefer revisionary expressivism to these other three positions. ${ }^{4}$

\footnotetext{
${ }^{4}$ I thank two anonymous reviewers for very helpful feedback on this paper.
} 


\section{$\underline{\text { References }}$}

Ayer, A.J. 1952. Language, Truth, and Logic. Mineola: Dover.

Bedke, Matthew 2010. Might All Normativity Be Queer?, Australasian Journal of Philosophy 88/1: 4158.

Blackburn, Simon 1984. Spreading the Word: Groundings in the Philosophy of Language, Oxford: Clarendon Press.

Blackburn, Simon 1993. Attitudes and Contents, in Essays in Quasi-Realism, pp. 182-197, New York, Oxford University Press.

Blackburn, Simon. 1993. Errors and the Phenomenology of Value, in Essays in Quasi-Realism, pp. 149165, New York, Oxford University Press.

Blackburn, Simon 2001. Ruling Passions: A Theory of Practical Reasoning, New York: Oxford University Press.

Dreier, James 2004. Meta-Ethics and the Problem of Creeping Minimalism, Philosophical Perspectives 18/1: 23-44.

Eklund, Matti 2011. Fictionalism, in The Stanford Encylcopedia of Philosophy, edited by E. N. Zalta, The Metaphysics Research Lab, Stanford.

Garner, Richard 2007. Abolishing Morality, Ethical Theory and Moral Practice 10/5: 499-513.

Geach, Peter 1958. Imperative and Deontic Logic, Analysis 18/3: 49-56.

Geach, Peter 1965. Assertion, The Philosophical Review 74/4: 449-465.

Gibbard, Allan 1992. Wise Choices, Apt Feelings: A Theory of Normative Judgment, Oxford: Clarendon Press.

Gibbard, Allan 2008. Thinking How to Live, Cambridge: Harvard University Press.

Hale, Bob 2002. Can Arboreal Knotwork Help Blackburn out of Frege's Abyss?, Philosophy and Phenomenological Research 65/1: 144-149.

Hinckfuss, Ian 1987. The Moral Society: Its Structures and Effects, Discussion Papers in Environmental Philosophy, Canberra: Australian National University. 
Hume, David 2007 [1739]. A Treatise of Human Nature, D. Fate Norton and M. J. Norton, eds., Oxford: Clarendon Press.

Kalderon, Mark Eli 2011. Moral Fictionalism, Oxford: Oxford University Press.

Joyce, Richard 2001. The Myth of Morality, Cambridge: Cambridge University Press.

Joyce, Richard 2009. Moral Anti-Realism, in The Stanford Encyclopedia of Philosophy, edited by E. N. Zalta, Metaphysics Research Lab, Stanford.

Köhler, Sebastian and Michael Ridge 2013. Revolutionary Expressivism, Ratio 26/4: 428-449.

Lewis, David 1978. Truth in Fiction, American Philosophical Quarterly 15/1: 37-46.

Mackie, John 1977. Ethics: Inventing Right and Wrong, New York: Penguin.

Moore, G. E. 1903. Principia Ethica, New York: Cambridge University Press.

Nolan, Daniel, Greg Restall, and Caroline West 2005. Moral Fictionalism Versus the Rest, Australasian Journal of Philosophy 83/3: 307-330.

Olson, Jonas 2011. Getting Real About Moral Fictionalism, in R. Shafer-Landau, ed., Oxford Studies in Metaethics, Volume 6, Oxford: Oxford University Press: 181-204.

Olson, Jonas 2014. Moral Error Theory: History, Critique, Defence, Oxford: Oxford University Press.

Ridge, Michael 2007. Expressivism and Epistemology: Epistemology for Ecumenical Expressivists, Proceedings of the Aristotelian Society, Supplementary Volume 81/1: 83-108.

Schroeder, Mark 2008. What Is the Frege-Geach Problem?, Philosophy Compass 3/4: 703-720.

Shafer-Landau, Russ 2003. Moral Realism: A Defence, Oxford: Clarendon Press.

Smith, Michael 1987. The Humean Theory of Motivation, Mind 96/381: 36-61.

Smith, Michael 1994. The Moral Problem, Malden: Blackwell.

Sobel, David, and David Copp 2001. Against Direction of Fit Accounts of Belief and Desire, Analysis 61/269: 44-53.

Stevenson, Charles L. 1979. Ethics and Language, New York: AMS Press.

Streumer, Bart 2013. Can We Believe the Error Theory, Journal of Philosophy 110/4: 194-212. 